\title{
Effect of Biomaterial Treatments on the Storage Stability and Quality of Cowpea
}

\author{
Joseph Shian Alakali ${ }^{1, ~ *, ~ I g n a t i u s ~ C h u k w u e m e k a ~ A l a k a ~}{ }^{2}$, Patience Dooshima Nomji ${ }^{1}$ \\ ${ }^{1}$ Department of Food Science and Technology, University of Agriculture Makurdi, Nigeria \\ ${ }^{2}$ Department of Food Science and Technology, Ebonyi State University, Abakaliki, Nigeria
}

\section{Email address:}

alakaignatius@gmail.com (J. S. Alakali)

${ }^{*}$ Corresponding author

\section{To cite this article:}

Joseph Shian Alakali, Ignatius Chukwuemeka Alaka, Patience Dooshima Nomji. Effect of Biomaterial Treatments on the Storage Stability and Quality of Cowpea. American Journal of Life Sciences. Vol. 4, No. 6, 2016, pp. 181-186. doi: 10.11648/j.ajls.20160406.16

Received: October 7, 2016; Accepted: October 26, 2016; Published: December 12, 2016

\begin{abstract}
The insecticidal effect of four biomaterials namely, Garlic (Al. sativum), Ginger (Zingiber officinale), Black pepper (Piper guineese L.) and Lemon grass (Cymbopogon citrates Staph) leaf powders, applied at $10 \%$ and 5\% concentration on Cowpea grains against the Cowpea weevils (Callosobruchus maculatus fab.) were evaluated after 42 days. Their effectiveness at both dosages on proximate composition, grain damage, progeny development, grain loss and frass weight were determined. Use of the biomaterials showed good retention of some nutrients like protein and fat and did not adversely affect the other nutritional parameters. The carbohydrate values of treated samples were slightly lower $(54.47-58.55 \%)$ for $10 \%$ and $(54.56-59.53)$ for $5 \%$. than the control $(60.83-61.24)$. There was no significant difference $(p \leq 0.05)$ in the ash contents among biomaterials. The biomaterials showed effective control of cowpea seed damage, weevil perforation index, progeny development, and weight loss and frass weight. These effects were more at $10 \%$ concentration than at $5 \%$. Their efficacy in order of effectiveness are as follows black pepper $>$ ginger $>$ garlic $>$ lemon grass. The biomaterials, especially black pepper and ginger are good alternative to the use of chemicals for preservation of cowpea.
\end{abstract}

Keywords: Biomaterial, Cowpea, Weevils, Cowpea Damage, Weight Loss Progeny

\section{Introduction}

Cowpea (Vigna unguiculata L) is an important grain legume in Nigeria. It is one of the most important crops for both human and animal consumption [13]. The protein found in cowpea is similar to that in most legumes, rich in the essential amino acids lysine and tryptophan [27]. Cowpea has therapeutic and protective effects in hypercholesterolemia, cardiovascular diseases, and cancer [13].

The production of cowpea in Nigeria is rapidly on the increase due to improved seed varieties and good cultural practices as well as incentives to farmers by the government [12]. This production boom has been adversely affected by the postharvest losses of the commodity which are usually encountered, mostly during storage [7].

Cowpea weevil (Callosobruchus maculatus) is a major pest of stored grains in the tropics and temperate regions of the world [3]. Its infestation causes severe postharvest losses of the grains in Nigeria leading to major economic losses [21]. Cowpea utilization is reduced due to grain destruction by cowpea weevils which inevitably increase food insecurity to farmers that depend on the crop for their livelihood [14]. Post-harvest losses and quality deterioration caused by the storage pests are a major problem facing cowpea utilization in Nigeria [2, 14]. Once infestation is established, weevils cause gradual and progressive damage leading to losses in weight, nutritional, organoleptic and aesthetic quality of the stored grains $[17,11]$.

The use of chemicals for control of these pests is common in Nigeria. However, this is known to be costly and environmentally hazardous to man. The above underscores renewed attention by researchers on the use of locally available plant materials for storage of grains in recent times [14]. Traditionally, farmers have been using available indigenous knowledge systems to successfully manage pests depending on their location [24]. The use of ethno-botanical chemicals and cultural practices as management measures to 
reduce postharvest losses of grains had been reported by [19]. Natural methods of plant protection are assuming new importance as an alternative to commercial synthetic products, which are expensive, unavailable at critical periods and may pose health hazards to man and livestock [22]. As a matter of fact, many reported cases of food poisoning are traceable to the use of chemicals for the preservation of grains [6].

Various plant materials such as Neen (Azadiracta indica), pepper fruit seed (Denitta tripetata), and soybean oil (Glycine max) have been tested and recommended for grain storage and germination especially for maize and cowpea. These plant materials are cheap, locally available and environmentally friendly and nontoxic both to man and livestock [12]. Earlier work by [15] showed that plant materials contain naturally occurring phytochemicals that are biodegradable, nontoxic to plants and animals. It is desirable to replace the use of synthetic chemicals for the storage of grains so as to reduce cases of food poisoning and environmental hazards. It is therefore the objective of this work to evaluate the efficacy of some pulverized biomaterials such as Garlic (Al. sativum), Ginger (Zingiber officinale), Black pepper (Piper guineese L.) and Lemon grass (Cymbopogon citrates Staph) leaf powders on storage stability and quality of cowpea.

\section{Materials and Methods}

\subsection{Preparation of Insect Cultures}

Newly emerged adult C. maculatus weevils used for this work were obtained from already existing culture in the Crop and Soil Sciences, University of Agriculture, Makurdi, Benue State, Nigeria. They were reared inside 1 litre Kilner jar, on uninfested and insecticide free cowpea seeds. The culture was kept safe in a wooden cabinet at room temperature $\left(25^{\circ} \mathrm{C}\right)$ and $70 \pm 5 \%$ relative humidity for a month to allow for the multiplication of the weevils.

\subsection{Preparation of Plant Materials}

Garlic (Allium sativum), Ginger (Zingiber officinale ), black pepper

(Piper guineese L.), and lemon grass leaves (Cymbopogon citrates Staph) were processed using the methods described by [8]. These plant materials were dried in an open laboratory and ground into very fine powder using an electric blender. The powders were further sieved to pass through a $0.05 \mathrm{~mm}$ sieve and $500 \mathrm{~g}$ each of plant material powders were obtained. They were immediately packed in plastic bottles and stored in a refrigerator at $4^{\circ} \mathrm{C}$ to minimize loss of volatile organic substances.

\subsection{Collection of Cowpea Seeds}

Cowpea grains that are not infested and free of insecticides treatment were sourced from the Agricultural Development Programme (ADP) Makurdi, Benue State Nigeria. They cowpea were cleaned and kept in a deep freezer at $-5^{\circ} \mathrm{C}$ for
$96 \mathrm{~h}$ to disinfect/ kill all hidden infestations. They were later dried in a Gallenkamp air oven (Model 250) at $40^{\circ} \mathrm{C}$ for 4 hours to prevent mould growth as described by [1].

\subsection{Treatment of Samples and Bioassay}

Two sets of cowpea seeds each weighing $200 \mathrm{~g}$ and $400 \mathrm{~g}$, were infested with 20 pairs of day old adults C. maculatus weevils (male and female) and treated with $20 \mathrm{~g}$ of each biomaterial amounting to $10 \%$ and $5 \%$ treatments respectively. The containers with their contents were gently shaken to ensure thorough admixture of the cowpea seeds and treatment powders. The treated samples were stored in a jar covered with muslin cloth ensuring an ambient temperature of $30 \pm 3^{\circ} \mathrm{C}$ and $70 \pm 5 \% \mathrm{RH}$ are maintained according to the methods of [20], and [3]. The treated samples were observed for 6 weeks (42 days). A control treatment containing $200 \mathrm{~g}$ cowpea infested with twenty pairs of weevils (male and female) in a covered jar with no plant material was also monitored for the same period of time.

At the end of the 42-day observation period, the extent of weevil damage was assessed using the exit-holes as a measure of damage to the grains. The percentage damage (PD) and weevil perforation index (WPI) of the weevils to the grains was calculated using the methods described by [2].

$$
\begin{gathered}
\mathrm{PD}=\frac{\text { Total number of treated grains perforated }}{\text { Total number of grains }} \times 100 \\
\mathrm{WPI}=\frac{\% \text { of treated grains perforated }}{\% \text { of control grains perforated }} \times 100
\end{gathered}
$$

The total number of insects present in both treated and untreated glass jars were counted to determine weevil progeny development according to the method described by [23]. The grain weight loss was calculated by obtaining the difference in weights of the grains before and after treatments of grain as described by [18]. Frass weight was also recorded.

\subsection{Determination of Proximate and Carbohydrate Composition}

Moisture content, crude protein, crude fat, fibre and ash content of samples were determined by the method described by [5]. The carbohydrate content was obtained by subtracting the values of moisture, total ash, lipid, crude fibre and crude protein $([4]$.

\subsection{Phytochemical Analysis}

The gravimetric method of Harbone as described by [25], was adopted for the determination alkaloids and flavonoids. The Spectrophotometric method was used for saponin analysis as described by [25]. Swain's method as described by [25] was used for Tannins determination.

\subsection{Statistical Analysis}

Data were subjected to analysis of variance and where significant difference existed, treatment means were 
separated using the new Duncan's Multiple Range Test [28].

\section{Results and Discussion}

\subsection{Proximate Composition}

Results of proximate analysis of treated cowpea are presented in Table 1. The results reveal that the moisture content (MC) of the samples treated with biomaterial at 5\% and $10 \%$ were significantly $(\mathrm{p} \leq 0.05)$ lower than the control. However, there was no significant difference $(p \geq 0.05)$ in the moisture content of samples treated with Garlic, Ginger and Lemon, but the values were significantly $(\mathrm{p} \leq 0.05)$ higher than the Black pepper treated samples. This indicates that Black pepper will keep the cowpea longer during storage. The low MC of treated cowpea suggests that biomaterials could help in extending the shelf life of cowpea while under storage. The dried nature of the biomaterials may have favoured moisture absorption from the cowpea seeds, thus influencing the moisture values.

Ash content of the Ginger, Garlic and Lemon grass treated cowpea with $5 \%$ and $10 \%$ concentration did not differ significantly from the control $(\mathrm{p} \leq 0.05)$. However, the ash content values of Black pepper treated samples were higher and differed significantly ( $\mathrm{p} \geq 0.05$ ) with the other samples. Black pepper may have repelled weevils from eating up the grain's endosperm and therefore responsible for the higher ash content. Variations in the ash content values of samples treated with different biomaterials were due to the differences in the strength of the biomaterials to repel weevils from damaging the grains. Consequently, cowpea seeds treated with biomaterials that showed higher weevil repulsion were generally seen to have higher ash content.

The protein content of cowpea treated with $5 \%$ and $10 \%$ biomaterials were significantly $(p \leq 0.05)$ higher than the control (Table 1). However, the $10 \%$ treated samples had slightly higher protein than the $5 \%$. The high protein content in treated samples indicates that the biomaterials were able to protect the cowpea seeds from weevil's damage. This is evident in the fact that grains treated with $10 \%$ biomaterials, which showed greater protection of the grain from weevil damage, had higher protein content compared with the $5 \%$, while the untreated (control) had lower values.

The fat contents of the samples treated with $5 \%$ and $10 \%$ concentrations were significantly $(p \geq 0.05)$ higher than the control, following the same pattern observed in the protein content (Table 1). The lower fat observed in the control, was likely due to insect's activity that bole holes in the grain endosperm, exposing it to factors that favoured more breakdown of fat to fatty acids as stated by [16].

The carbohydrate values of the treated cowpeas at both $5 \%$ and $10 \%$ concentrations were significantly $(\mathrm{p}<0.05)$ lower than the control. In both treatments, the carbohydrate values of Black pepper treated samples, which has higher resistance to weevil attack were lower than the other samples. Similar trend was observed in the fibre content of samples. This result indicates that the biomaterial inhibited the activities of weevils and prevented the depletion of the other nutrients in the cowpea, but had no influence on the carbohydrate and fibre content. On the other hand, more insect feeding on the endosperm of untreated grains (control) may have decreased the total protein content, thereby increasing the total carbohydrate values. The endosperm component of grains contains much of the seeds protein which is readily damaged by insects [9].

The use of biomaterials showed good retention of the major nutrients like protein, and fat during storage. The biomaterials may have reduced the respiratory activities of the weevils, thereby resulting in asphyxiation and subsequent death [2].

\subsection{Effect of Biomaterial on Stored Cowpea Grains}

The effect of biomaterial treatments on cowpea seed damage, weevil perforation index, progeny development, grain weight loss and frass weight are as presented in Table 2. The results show that the use of biomaterials at both $5 \%$ and $10 \%$ reduced seed damage, weevil perforation, progeny development, grains weight loss and frass weight. The percentage seed damage of the treated samples ranged from $0.5 \%-2.50 \%$, compared with $7.00 \%$ for the untreated (control) samples. The result indicates that $10 \%$ was more effective in reducing grain damage than $5 \%$. The percent seed damage was lowest in Black pepper treated samples ( 0.51 for $5 \%$ and 0.50 for $10 \%$ ), while the highest damage was observed in Lemon grass treated samples (2.50 for both $5 \%$ and $10 \%$ ). Garlic followed Black pepper in the ability to reduce seed damage. The result shows that both $5 \%$ and $10 \%$ had the same effect on seed damage reduction. The results clearly indicate that the biomaterials differed in their effectiveness in controlling grain seeds damage. Black pepper was more effective and lemon grass was least effective.

The Weevil Perforation Index (WPI) ranged from 2.04 to 6.79 for biomaterials treated cowpea, while the control was 8.00. As observed in seed damage, samples treated with $10 \%$ of the biomaterials showed less weevil perforation than the $5 \%$. The Cowpeas seeds treated with ginger powder had the lowest perforation index $(2.13-2.24)$, followed by garlic powder (2.13 -2.24), while Lemon grass had the highest perforation $(6.29-6.79)$. The results show that WPI of biomaterials treated samples were generally lower than that of the control.

All biomaterials showed minimal progeny development ranging from 19 - 33 compared to $36-44$ in the control. At $10 \%$ concentration, progeny development was higher than $5 \%$ in all treatments but more obvious in garlic and ginger. Garlic powder had greater tendency to inhibit weevil progeny development than the other biomaterials. The reduction in progeny emergence in the treated grains might be due to increased adult mortality, ovicidal and larvicidal properties of the tested biomaterials as reported by [9]. It was also noted [26] that all concentrations of dry ground leaves of $C$. ambrosoides resulted in complete $(100 \%)$ inhibition of oviposition and progeny production by $C$. chinensis, $C$. 
maculatus and A. obtectus and killed the larvae hatching from eggs laid on grains, preventing feeding and damage.

Cowpea seeds treated with biomaterials had a lower grain weight loss of $14.47 \%-20.00 \%$ corresponding to $10 \%$ and $5 \%$ biomaterials respectively, as against $41.33 \%-42.00 \%$ of the control samples. The $10 \%$ treated samples showed more weight loss than the 5\%. Garlic treated samples had the lowest weight loss of $14.47 \%$ and $14.76 \%$ at $10 \%$ and $5 \%$ respectively. The other biomaterials, ginger (15.66 - 16.66\%), lemon grass $(19.34-20.00 \%)$ and black pepper (17.42 $17.60 \%$ ) also showed good promise for checking grain weight loss.

The frass weight of treated samples ranged from 0.13 $1.63 \mathrm{mg}$ while the untreated ranged from $1.78-2.00 \mathrm{mg}$ at $5 \%$ and $10 \%$ levels of treatment respectively. Among the treatments the least frass weight was observed with garlic powders $(0.13 \mathrm{mg})$ and $(0.34 \mathrm{mg})$ at $10 \%$ and $5 \%$. This was followed by ginger powder $(1.23 \mathrm{mg})$ and $(1.30 \mathrm{mg})$ frass in $10 \%$ and $5 \%$ concentration of treatment respectively. The lemon grass powder was the least effective with $(1.51 \mathrm{mg})$ and $(1.63 \mathrm{mg})$ frass weight. Frass weight was observed to decrease with increasing concentrations of the biomaterials used. The result shows that the reduced frass weights indicate that the level of activity of the weevils was disrupted during storage due to the action of biomaterials.

The inhibitory action of these plant powders may be due to the active components which have insecticidal properties against the weevils. For example, garlic has been reported to exhibit anti-viral, anti-bacterial, antifungal and anti-oxidant abilities due to its sulfur containing compounds, high trace mineral content and enzymes. The effectiveness of these powders may be through their impact onthe breathing system of the insect through blockage of spiracles preventing oxygen inhalation leading to deaths of weevils [10].

\subsection{Phytochemical Composition of Treated Cowpea Seeds}

The result of some anti-nutrients composition of treated cowpea samples are as shown in Table 2. The study showed that the anti-nutrients levels reduced with storage time. The tannin, saponin and alkaloids in cowpea treated samples were lower than that of the control at both $10 \%$ and $5 \%$ concentrations. The cowpea had more saponin and alkaloid than tannin, but in all the treatments had very low concentration of the anti-nutrients. Tannin content showed no significant different $(\mathrm{p} \leq 0.05)$ in ginger, garlic and lemon but significant difference $(p \leq 0.05)$ in black pepper and the control treatment. It is however not discernable the sequence of the biomaterials reaction. The result also showed that Flavonoid concentration increased with biomaterial treatments in the $10 \%$ treatment. This is expected since the biomaterials are of plant sources rich in antioxidants.

Table 1. Proximate Composition of treated Cowpea grains (\%).

Powders at $10 \%$ concentration

\begin{tabular}{|c|c|c|c|c|c|c|}
\hline & Control & Ginger & Garlic & Lemon Grass & Black Pepper & LSD \\
\hline Moisture & $9.24^{\mathrm{a}} \pm 0.02$ & $8.70^{b} \pm 0.27$ & $8.87^{b} \pm 0.17$ & $8.87^{b} \pm 0.18$ & $8.33^{c} \pm 0.09$ & 0.18 \\
\hline Ash & $4.26^{\mathrm{b}} \pm 0.12$ & $4.45^{\mathrm{b}} \pm 0.01$ & $4.06^{b} \pm 0.21$ & $4.06^{b} \pm 0.18$ & $5.36^{\mathrm{a}} \pm 0.31$ & 0.21 \\
\hline Protein & $20.00^{c} \pm 0.12$ & $23.43^{\mathrm{a}} \pm 0.10$ & $22.33^{b} \pm 0.16$ & $22.33^{b} \pm 0.10$ & $23.40^{\mathrm{a}} \pm 0.24$ & 0.18 \\
\hline Fat & $1.43^{\mathrm{d}} \pm 0.25$ & $2.71^{\mathrm{a}} \pm 0.06$ & $1.88^{\mathrm{c}} \pm 0.09$ & $1.88^{\mathrm{c}} \pm 0.29$ & $2.41^{b} \pm 0.24$ & 0.06 \\
\hline $\mathrm{CHO}$ & $61.24^{\mathrm{a}} \pm 0.23$ & $58.55^{\mathrm{c}} \pm 0.15$ & $58.86^{\mathrm{b}} \pm 0.54$ & $58.86^{b} \pm 0.15$ & $54.47^{d} \pm 0.34$ & 0.17 \\
\hline Fibre & $6.19^{\mathrm{a}} \pm 0.24$ & $2.02^{\mathrm{d}} \pm 0.12$ & $3.98^{\mathrm{c}} \pm 0.26$ & $3.98^{c} \pm 0.59$ & $5.55^{\mathrm{b}} \pm 0.20$ & 0.18 \\
\hline
\end{tabular}

Powders at 5\% concentration

\begin{tabular}{|c|c|c|c|c|c|c|}
\hline Parameter & Control & Ginger & Garlic & Lemon Grass & Black pepper & LSD \\
\hline Moisture & $9.63^{\mathrm{a}} \pm 0.21$ & $8.73^{b} \pm 0.24$ & $8.56^{\mathrm{c}} \pm 0.14$ & $8.56^{\mathrm{c}} \pm 0.11$ & $8.03^{\mathrm{d}} \pm 0.17$ & 0.13 \\
\hline Ash & $4.24^{\mathrm{b}} \pm 0.09$ & $4.38^{\mathrm{b}} \pm 0.24$ & $3.72^{c} \pm 0.16$ & $3.72^{\mathrm{c}} \pm 0.23$ & $5.89^{\mathrm{a}} \pm 0.02$ & 0.15 \\
\hline Protein & $20.56^{\mathrm{d}} \pm 0.02$ & $22.55^{\mathrm{b}} \pm 0.01$ & $21.12^{\mathrm{c}} \pm 0.03$ & $21.12^{\mathrm{c}} \pm 0.01$ & $22.87^{\mathrm{a}} \pm 0.03$ & 0.17 \\
\hline Fat & $1.37^{c} \pm 0.13$ & $1.49^{c} \pm 0.02$ & $1.85^{\mathrm{b}} \pm 0.12$ & $1.85^{\mathrm{b}} \pm 0.03$ & $2.74^{\mathrm{a}} \pm 0.03$ & 0.19 \\
\hline $\mathrm{CHO}$ & $60.83^{\mathrm{a}} \pm 0.14$ & $59.58^{\mathrm{b}} \pm 0.23$ & $59.46^{\mathrm{b}} \pm 0.32$ & $59.46^{\mathrm{b}} \pm 0.03$ & $54.56^{\mathrm{c}} \pm 0.24$ & 1.05 \\
\hline Fibre & $5.38^{\mathrm{b}} \pm 0.16$ & $2.95^{\mathrm{c}} \pm 0.06$ & $5.36^{\mathrm{b}} \pm 0.37$ & $5.26^{\mathrm{b}} \pm 0.26$ & $5.73^{\mathrm{a}} \pm 0.18$ & 0.18 \\
\hline
\end{tabular}

Values are means of triplicate determinations. Mean values with same superscript in a row are not significantly different ( $\mathrm{p} \geq 0.05 \mathrm{al})$.

Table 2. Effect of Biomaterial on Stored Cowpea.

\begin{tabular}{|c|c|c|c|c|c|c|c|c|c|c|}
\hline \multirow[t]{3}{*}{ Biomaterials } & \multicolumn{2}{|c|}{$\begin{array}{l}\% \text { Grain } \\
\text { Damage }\end{array}$} & \multicolumn{2}{|c|}{$\begin{array}{l}\text { Weevil perforation } \\
\text { index (WPI) }\end{array}$} & \multicolumn{2}{|c|}{ Progeny Development } & \multicolumn{2}{|c|}{$\begin{array}{l}\text { \%Gain } \\
\text { weight Loss }\end{array}$} & \multicolumn{2}{|c|}{$\begin{array}{l}\text { Frass weight } \\
(\mathrm{mg})\end{array}$} \\
\hline & \multicolumn{10}{|c|}{ Biomaterial Concentration } \\
\hline & $10 \%$ & $5 \%$ & $10 \%$ & $5 \%$ & $10 \%$ & $5 \%$ & $10 \%$ & $5 \%$ & $10 \%$ & $5 \%$ \\
\hline Ginger & 1.50 & 2.50 & 2.04 & 2.15 & 23 & 27 & 15.66 & 16.66 & 1.23 & 1.30 \\
\hline Garlic & 0.50 & 1.00 & 2.13 & 2.24 & 19 & 21 & 14.47 & 14.76 & 0.13 & 0.34 \\
\hline Lemon Grass & 2.50 & 2.50 & 6.29 & 6.79 & 28 & 33 & 19.34 & 20.00 & 1.51 & 1.63 \\
\hline Control & 7.00 & & 8.00 & & 44.00 & & 42.00 & & 2.00 & \\
\hline
\end{tabular}


Table 3. Phytochemical Composition of treated cowpea grains $(\mathrm{g} / 100 \mathrm{~g})$.

Powders at $10 \%$ concentration

\begin{tabular}{|c|c|c|c|c|c|c|}
\hline Parameter & Control & Ginger & Garlic & Lemon Grass & Black Pepper & LSD \\
\hline Tannin & $0.28^{\mathrm{a}} \pm 0.02$ & $0.25^{\mathrm{ab}} \pm 0.27$ & $0.14^{\mathrm{b}} \pm 0.17$ & $0.18^{\mathrm{ab}} \pm 0.18$ & $0.18^{\mathrm{ab}} \pm 0.09$ & 0.12 \\
\hline Saponin & $2.85^{\mathrm{a}} \pm 0.12$ & $1.86^{\mathrm{b}} \pm 0.01$ & $1.36^{\mathrm{c}} \pm 0.21$ & $1.32^{\mathrm{c}} \pm 0.18$ & $0.32^{\mathrm{d}} \pm 0.31$ & 0.11 \\
\hline Alkaloids & $1.10^{\mathrm{a}} \pm 0.12$ & $1.04^{\mathrm{ba}} \pm 0.10$ & $0.11^{c} \pm 0.16$ & $1.14^{\mathrm{a}} \pm 0.10$ & $0.14^{\mathrm{c}} \pm 0.24$ & 0.08 \\
\hline
\end{tabular}

Powders at 5\% concentration

\begin{tabular}{|c|c|c|c|c|c|c|}
\hline Parameter & Control & Ginger & Garlic & Lemon Grass & Black Pepper & LSD \\
\hline Tannin & $0.31^{\mathrm{a}} \pm 0.02$ & $0.25^{\mathrm{a}} \pm 0.27$ & $0.17^{\mathrm{b}} \pm 0.17$ & $0.25^{\mathrm{a}} \pm 0.18$ & $0.17^{b} \pm 0.09$ & 0.13 \\
\hline Saponin & $1.60^{\mathrm{a}} \pm 0.12$ & $1.47^{\mathrm{b}} \pm 0.01$ & $1.28^{\mathrm{cd}} \pm 0.21$ & $1.37^{\mathrm{bc}} \pm 0.18$ & $1.23^{\mathrm{d}} \pm 0.31$ & 0.11 \\
\hline Alkaloids & $1.03^{\mathrm{b}} \pm 0.12$ & $1.13^{\mathrm{a}} \pm 0.10$ & $0.02^{\mathrm{d}} \pm 0.16$ & $1.12^{\mathrm{ab}} \pm 0.10$ & $0.13^{\mathrm{c}} \pm 0.24$ & 0.18 \\
\hline Flavonoids & $0.65^{\mathrm{a}} \pm 0.25$ & $0.50^{\mathrm{b}} \pm 0.06$ & $0.41^{b c_{ \pm}} \pm 0.09$ & $0.43^{\mathrm{bc}} \pm 0.29$ & $0.28^{\mathrm{c}} \pm 0.24$ & 0.17 \\
\hline
\end{tabular}

Values are means of triplicate determinations. Mean values with same superscript in a row are not significantly different ( $\mathrm{p} \geq 0.05$ ).

\section{Conclusion}

The biomaterials used showed effectiveness in retaining nutrient quality of cowpea and reduction of grain damage, progeny development, grain weight loss and frass weight during storage. The effectiveness of the materials varied. Lemon grass showed poor activity on the weevils, whereas the ginger and garlic exhibited strong activity on progeny development and cowpea grain damage of cowpea weevil. In general, Black peper was most effective followed by ginger and garlic.

\section{References}

[1] Adedire C. O. and Lajide L. (2003). Ability of extract of ten tropical plant species to protect maize grains against infestation by maize weevil Sitophilus zeamais during storage, Niger. J. Exp. Biol., 4: 175-179.

[2] Adedire, C. O., \& Ajayi, T. S. (1996). Assessment of the insecticidal properties of some plant extracts as grain protection against the maize weevil, Sitophilus zeamais. Nigerian Journal of Entomology, 13, 93-101.

[3] Adedire, C. O. (2002). Use of nutmeg, Myristica fragrans (Houtt) powder and oil for the control of cowpea storage bruchid. Callosobruchus maculatus. Journal of Plant Diseases and Protection, 109, 193-199.

[4] Anitial, B. S., Akpan, E. J., Okon, P. A. and Umoren, I. U. (2006). Nutritive and antinutitive evaluation of sweet potatoes (Ipomoea batatas) leaves. Pak. J. Nutr., 5: 166-168.

[5] AOAC, (2005). Association of Official Analytical Chemists. Official Methods of Analysis. Association of Official Analytical Chemists. $18^{\text {th }}$ Ed., Arlington,

[6] Ashamo, M. O. (2007). Evaluation of contact toxicity and fumigant effect of some plant powders against Sitophilus zeamais (Mots.). Proceedings of the Akure- Humboldt Kellong ( $3^{\text {rd }}$ SAAT Annual Conference: Medicinal plants in Agriculture, The Nigeria Experience, pp. 64-67

[7] Arannilewa, S. T., Ekrakene T. and Akinneye. J. O. (2006). Laboratory evaluation of four medicinal plants as protectants against the maize weevil, Sitophilus zeemais (Mots). African Journal of Biotechnology Vol.5 (21) pp 2032-2036.
[8] Balestra GM, Heydari A, Ceccarelli D, Ovidi E, Quattrucci A (2009). Antibacterial effect of Allium sativum and Ficus carica extracts on tomato bacterial pathogens. Crop Protection 28:807-811.

[9] Bamaiyi, L. J., Onu, I.; Amatobi, C. I. and Dike, M. C. (2006). Effect of Callosobruchus maculatus Infestation on Nutritional Loss on Stored Cowpea Grains. Arch. Phytopath. Plant Prot. 39(2): 119-127.

[10] Danjumma, B. I., Majeed, Q., Abubakar, U. and Ibrahim, N. D. (2009). Effect of Pre-Treatment with Plant Powders on the Nutrient Composition of Maize Grain Zea Mays Infested by Weevil Sitophilus zeamais Motsch. Nig. J. of Basic and Applied Science. 17(2):211-217.

[11] Denloye, A. A., Makanjuola, W. A., Don-pendro, K. N. and Negbenebor, H. E. (2007). Insecticidal Effects of Tephrosia vogeli Hook (Leguminosae) leaf powder and extracts on Sitophilus zeamais Mostch, Callosobruchus maculatus F. and Tribolium castaneum Herbst. Nig. J. Entomol. (24): 91-97

[12] Duruigbo C. I. (2012). Assessing the Viability of Maize and Cowpea Seeds Stored Using Local Plant Biocides. International Journal of Biology Vol. 4, No. 2; April 2012

[13] En Ji Cul, Jin Gyeong Cho, In Sik Chung, Ji Young Kim, Seong Gil Hong and Nam In Baek. (2013). New Triterpenoid Saponins, Cowpeasaponins I and II, from Cowpea Seeds (Vigna sinensis K.). Notes Bull. Korean Chem. Soc. Vol. 34(8) pg 2499.

[14] Ileke, K. D., Odeyemi, O. O., Ashamo, M. O. (2012). Insecticide Activity of Alstonia boonie De Wild Powder against Cowpea Bruchid, Callosobruchus masclatus (Fab.)[Coleoptera: Chrysomelidae] in stored Cowpea Seeds. International Journal of Biology vol. 4(2) pg 125-131.

[15] Jackson, M (1983): Control of stored product insects with phytochemicals. Paper presented at the 3rd international working conference on stored products. Entomology Kansas state university, Oct 23-28 1983.

[16] Jood, S. and Kapoor, A. C. (1993). Protein and Uric acid Contents of Cereal Grains as Affected by Insect Infestation. Food Chem. 46: 143-146

[17] Lale N. E. S. (2002). Stored Products Entomology and Acarology. Mole Publications Nigeria Limited, Maiduguru, Nigeria. pp. 15-92. 
[18] Muhammad, S. (2010). Some possibilities on the effectiveness of plant powders as grain protectants against cowpea weevil, Callosobruchus maculates (Fabricius) Walp (Coleoptera: Bruchidea) infestation in chickpea. International Journal of Agronomy and Plant Production. Vol., 1 (2), 45-50.

[19] Mwololo J. K., Mugo S., Okori P. 1, Tefera T., Otim M. \& Munyiri S. W. (2012). 2012 doi:10.5539/jas.v4n11p206 URL: http://dx.doi.org/10.5539/jas.v4n11p206

[20] Odeyemi, O. O., \& Daramola, A. M. (2000). Storage practices in the tropics: Food storage and pest problems. First Edition, Dave Collins Publication, Nigeria, Vol. 1, 235.

[21] Oni M. O., and Ileke K. D., 2008, Fumigant toxicity of four botanical plant oils on survival, egg laying and progeny development of the dried yam beetle, Dinoderus porcellus (Coleoptera: Bostrichidae), Ibadan. J. Agricul. Res., 4: 31-36

[22] Oparaeke, A. M. and Dike, M. C. (2005). Comparison of garlic (Allium Sativum L.) and lemon grass (Cymbopogon citrates L.) products in the control of Callosobruchus maculatus Fab. (Coleoptera: Bruchidae) on stored cowpea grains. Nigerian Journal of Entomology, 13:73-80.

[23] Rotimi, J. and O. A. Ekperusi. (2012). Effectiveness of citrus oils as cowpea bruchid Callosobruchus maculates (F) (Cooleopteran: Bruchidae). Advances in Applied Science Research, 3 (6): 3540-3544.

[24] Sileshi, GW, Nyeko P, Nkunika, POY, Sekamatte BM, Akinnifesi FK, Ajayi OC. (2009). Integrating ethnoecological and scientific knowledge of termites for sustainable termite management and human welfare in Africa. Ecol Soc. 14(1):48

[25] Soladoye, M. O. and Chukwuma, E. C. (2012). Quantitative phytochemical profile of the leaves of Cissuspopulnea Guill. and Perr. (Vitaceae) - An important medicinal plant in central Nigeria. Arch. Appl. Sci.Res. 4:200-20

[26] Tapondjou L. A., Adler C., Bouda H., Fontem D. A. (2002). Efficacy of powder and essential oil from Chenopodium ambrosioides leaves as post-harvest grain protectants against six-stored product beetles. Journal of Stored Products Research.; 38(4): 395-402.

[27] Timko M. P and Singh BB. 2008. Cowpea, a multifunctional legume. In: Moore, P. H and Ming, R (eds) Genomics of tropical crop plants. Springer, New York, pp 227-257

[28] Zar, J. H. (1984). Biostatistical Analysis, $2^{\text {nd }}$ Edition,PrenticeHall International, Englewood Cliffs, N. J 